\title{
Effect of fire on a monodominant floating mat of Cyperus giganteus Vahl in a neotropical wetland
}

\author{
Rocha, M. ${ }^{a *}$, Santos Júnior, CC. ${ }^{b}$, Damasceno-Júnior, GA. ${ }^{a}$, Pott, $V J .{ }^{a}$ and Pott, $A .{ }^{a}$ \\ aPrograma de Pós-graduação em Biologia Vegetal, Centro de Ciências Biológicas e da Saúde, Universidade Federal de \\ Mato Grosso do Sul - UFMS, Cidade Universitária, s/n, CP 549, CEP 79070-900, Campo Grande, MS, Brazil \\ ${ }^{\text {b} C u r s o ~ d e ~ C i e ̂ n c i a s ~ B i o l o ́ g i c a s, ~ P r o g r a m a ~ d e ~ I n i c i a c ̧ a ̃ o ~ C i e n t i ́ f i c a, ~ C e n t r o ~ d e ~ C i e ̂ n c i a s ~ B i o l o ́ g i c a s ~ e ~ d a ~ S a u ́ d e, ~ U n i v e r s i d a d e ~}$ \\ Federal de Mato Grosso do Sul - UFMS, Cidade Universitária, s/n, CP 549, CEP 79070-900, Campo Grande, MS, Brazil \\ *e-mail: mairarocha.bot@gmail.com
}

Received: May 22, 2013 - Accepted: January 6, 2014 - Distributed: March 31, 2015

(With 6 figures)

\begin{abstract}
The rhizomatous Cyperus giganteus, abundant in the Pantanal wetland, can dominate extense floodable areas as monodominant communities. The Jacadigo lake has a large area of $C$. giganteus, where we performed an evaluation on community structure during two months in 2010 , before it was hit by a wildfire which top-killed the vegetation, compared to ten months post-fire. We utilized 40 plots of $1 \mathrm{~m} \times 1 \mathrm{~m}$, along permanent trails, assessing two strata: the upper, near the inflorescence of adult plants, and the lower, close to the water level. Our results show that fire does not affect dominance of $C$. giganteus, as it maintained the same cover as before fire; species richness is not much altered either -28 before fire and 34 thereafter. Fire changed the floristic composition, due to the annual variation of species and the ability of some plants to colonize gaps and to regrow after fire from underground organs and seeds. The stratification of the vegetation with characteristic species of upper and lower strata was similar after fire.
\end{abstract}

Keywords: Cyperaceae, floating meadow, diversity, Pantanal, plant succession.

\section{Efeito do fogo sobre uma comunidade monodominante de Cyperus giganteus Vahl em uma área úmida neotropical}

\begin{abstract}
Resumo
A planta rizomatosa Cyperus giganteus, encontrada no Pantanal, pode dominar extensas áreas inundáveis, formando uma comunidade monodominante chamada localmente de pirizal. A lagoa do Jacadigo, situada na sub-região de Nabileque, possui uma extensa área de pirizal onde foi realizada uma avaliação na estrutura da vegetação durante dois meses no período de 2010, antes de ser atingida por um incêndio que causou perda da cobertura aérea da vegetação e foi comparada com 10 meses de avaliação pós-fogo. Com indicações na literatura de que o rizoma da planta pode favorecer a espécie através de rebrotamento após um incêndio, o objetivo deste trabalho foi avaliar as variações na estrutura da vegetação de pirizal após um evento de fogo. Foram utilizadas 40 parcelas não fixas de $1 \mathrm{~m} \times 1 \mathrm{~m}$ e alocadas sistematicamente através de trilhas avaliando dois estratos: o superior, próximo a inflorescência dos adultos e o inferior, próximo a lâmina d'água. Nos dois meses logo após o fogo, devido ao tamanho reduzido nos indivíduos de $C$. giganteus foi avaliado apenas um estrato denominado total. Os resultados mostram que o fogo não afeta a dominância de $C$. giganteus, que se mantém na mesma faixa de cobertura do período anterior ao fogo; a riqueza de espécies não é alterada, 28 no período anterior ao fogo e 34 no período posterior. Após o incêndio, a estrutura da comunidade sofre alteração na composição florística, devido a mudança anual de espécies e a capacidade que certas plantas possuem em colonizar clareiras e rebrotar após o fogo por meio de órgãos subterrâneos e sementes. A estratificação da vegetação com espécies características de estrato superior e inferior se manteve após o fogo, porém com diferença menos acentuada entre as espécies.
\end{abstract}

Palavras-chave: Cyperaceae, baceiro, diversidade, Pantanal, sucessão vegetal.

\section{Introduction}

In some wetlands fire is a frequent and important disturbance, and only tolerant species persist; a wildfire can open gaps in the vegetation, followed by secondary succession at recovery (Cronk and Fennessy, 2001). In swamps, burnings are not frequent, due to standing water, but can be a significant factor during droughts (Mitsch and

Gosselink, 2000). For instance, in the Okavango delta, floodplains can have high frequency of fire (Heinl et al., 2007).

Effects of fire can be detrimental or favorable. In a monodominant bamboo Bambusa arnhemica stand, in a floodable area in Australia, fire destroys some culms 
and reduces subsequent survival, leading to a decline of tussock basal area (Franklin et al., 2010). In yearly burned grasslands in austral Brazil, some herbs present higher abundance compared to areas protected from fire (Fidelis et al., 2007). In wet grasslands of cerrado, burning favors some Eriocaulaceae but hinders others (Neves et al., 2011).

Consequences of fire on aquatic herbaceous monodominant formations are yet little known in the Neotropics. Communities have dynamic species composition, with change of species continuously entering and leaving the system, very evident when there is an external disturbance, such as fire, capable to affect the ecological succession (Pinto-Coelho, 2000). The study of effects of fire allows to understand survival mechanisms, such as underground storage organs in Richardia grandiflora and Vernonia flexuosa which have regrowth capacity after loss of aerial biomass by fire (Fidelis et al., 2007).

The Pantanal has a dynamic vegetation in time and space, due to factors which include hydrological fluctuations, successional processes and intensity of land use, such as fire (Pott and Pott, 2003). Burning in the region is traditionally used as management practice of natural grasslands, for renewal or control of coarse grasses (Allem and Valls, 1987; Couto et al., 2006). Wildfires are concentrated at the end of the dry season in August and September, under low relative humidity, associated with accumulated flammable dry matter (Couto et al., 2006; Crispim et al., 2009).

Effects of fire on the Pantanal flora are controversial, as they depend on vegetation type, if dry or wet grassland, cerrado savanna or forest, being detrimental on flood tolerant plants with exposed buds (Pott, 2007). Nevertheless, a high number of aquatic species is cited as fire tolerant in the Pantanal, such as Cyperus giganteus, giant flatsedge, a rhizomatous herb which forms monodominat stands (Pott and Pott, 2000). Dominance of C. giganteus has indications in the literature of being favored by fire (Pott and Pott, 2000).

In the Pantanal, the Jacadigo lake has an extense area covered by aquatic vegetation with monodominant community of $C$. giganteus. In 2010, during a survey on this vegetation, a wildfire occurred, destroying all above ground biomass and we decided to assess its effects. So, our study aims to describe variations in community structure of $C$. giganteus before and after fire, testing the following hypothesis: fire contributes to increase dominance of C. giganteus.

\section{Material and Methods}

\subsection{Study area}

The Pantanal, in Central West of Brazil, is an extremely flat floodplain, over hundreds of kilometers, with declivity of 3-15 $\mathrm{cm}_{-} \mathrm{km}^{-1}$ North-South and $30-50 \mathrm{~cm}_{-} \mathrm{km}^{-1}$ East-West, what determines delayed outflow (Adámoli, 2000). The climate of the Pantanal is characterized by dry winters and rainy summers, named "Aw" by Köppen
(1948). Mean annual rainfall in 1975-1996 was $1,070.0$ mm (Soriano, 1997).

Our study was carried out in Jacadigo lake, a shallow fresh water neotropical lake, with clayey-organic sediment, situated on the right margin of the Paraguay river (Bezerra and Mozeto, 2008), in the sub-region of Nabileque (Silva and Abdon, 1998), ca. $85 \mathrm{~m}$ altitude, in the municipality of Corumbá (Pereira and Lapere, 2009). The lake is fed by rain runoff and the Urucum creek, plus extraordinary overflow from the Paraguay river (Pereira and Lapere, 2009), ca. $40 \mathrm{~km}$ away. The overall vegetation is of foodable savanna type and one of the outstanding herbaceous species is $C$. giganteus, which occurs in high frequency within Copernicia alba stands (Allem and Valls, 1987) and in this lake.

The Jacadigo lake shrank in the decade 2000 (Pereira and Lapere, 2009). Macedo et al. (2009) verified that low water levels of the Paraguay river in 2008 and 2009, due to less rainfall on the watershed, caused increase of wildfires in the Pantanal, due to drying off of floodable areas, making the vegetation fire-prone, from spread of natural or anthropogenic focuses. The studied vegetation burns every few years, when the lake level is low, like in 2010. The fire occurred in September 2010 and reached the entire patch of $C$. giganteus in Jacadigo lake. We did not measure duration of the fire, but we estimate that it lasted up to two days, considering the size of the burned patch.

The area of $C$. giganteus which partially covers the Jacadigo lake has approximately $184,377 \mathrm{~m}^{2}$ and the study area $20,080 \mathrm{~m}^{2}$, situated on the southeast portion of the lake, close to the road BR-262, at the coordinates $19^{\circ} 18^{\prime} 10^{\prime \prime} \mathrm{S}$ and $57^{\circ} 36^{\prime} 28.2^{\prime \prime} \mathrm{W}$ (Figure 1). The studied C. giganteus stand is a floating mat on a histosol layer ca. $70 \mathrm{~cm}$ deep, with entangled rhizomes of the sedge.

Monodominant stands of $C$. giganteus are very common in floodable areas, occurring from Mexico to South America, in Brazil, Argentina, Uruguay, Paraguay and Bolivia. It is a rhizomatous emergent aquatic herb, resembling papyrus (C. papyrus L.), with thick and spongy stem, 1.5-2.5m tall (Pott and Pott, 2000; Lorenzi, 2008). The rhizomes are thick and rich in aerenchyma, growing within the first $10 \mathrm{~cm}$ of soil (Schessl, 1999). It is one of the few aquatic species of the $\mathrm{C}_{4}$ type, doing photosynthesis even on the inflorescence, which may be sterile (Pott and Pott, 2000).

\subsection{Sampling of plant cover}

We performed monthly samplings from July 2010 to September 2011. We placed 40 quadrats systematically along trails using a PVC frame $(1 \mathrm{~m} \times 1 \mathrm{~m})$, separated by a distance of approximately $5 \mathrm{~m}$, each month following trails established during field work. So, with 14 sampling dates, the total reached 560 quadrats, or $560 \mathrm{~m}^{2}$. We estimated visually the percentage of cover of the species per plot, except September 2010, when fire occurred in the area, the only period when the vegetation could not be sampled.

Considering that the sedge is above $1.8 \mathrm{~m}$ tall and its inflorescences form a continuous layer, we sampled two 
strata of the vegetation: one close to the inflorescences of green adult individuals (upper stratum) and the understory near the water (lower stratum) (Figure 2A). In October and November 2010, soon after the wildfire, we sampled only one stratum which was named total, since the reduced size of resprouting individuals of $C$. giganteus impeded sampling of both strata (Figure 2B).

All plant species found fertile were collected, pressed, oven dried and later identified with help of literature, by comparison with specimens in the Herbarium CGMS of

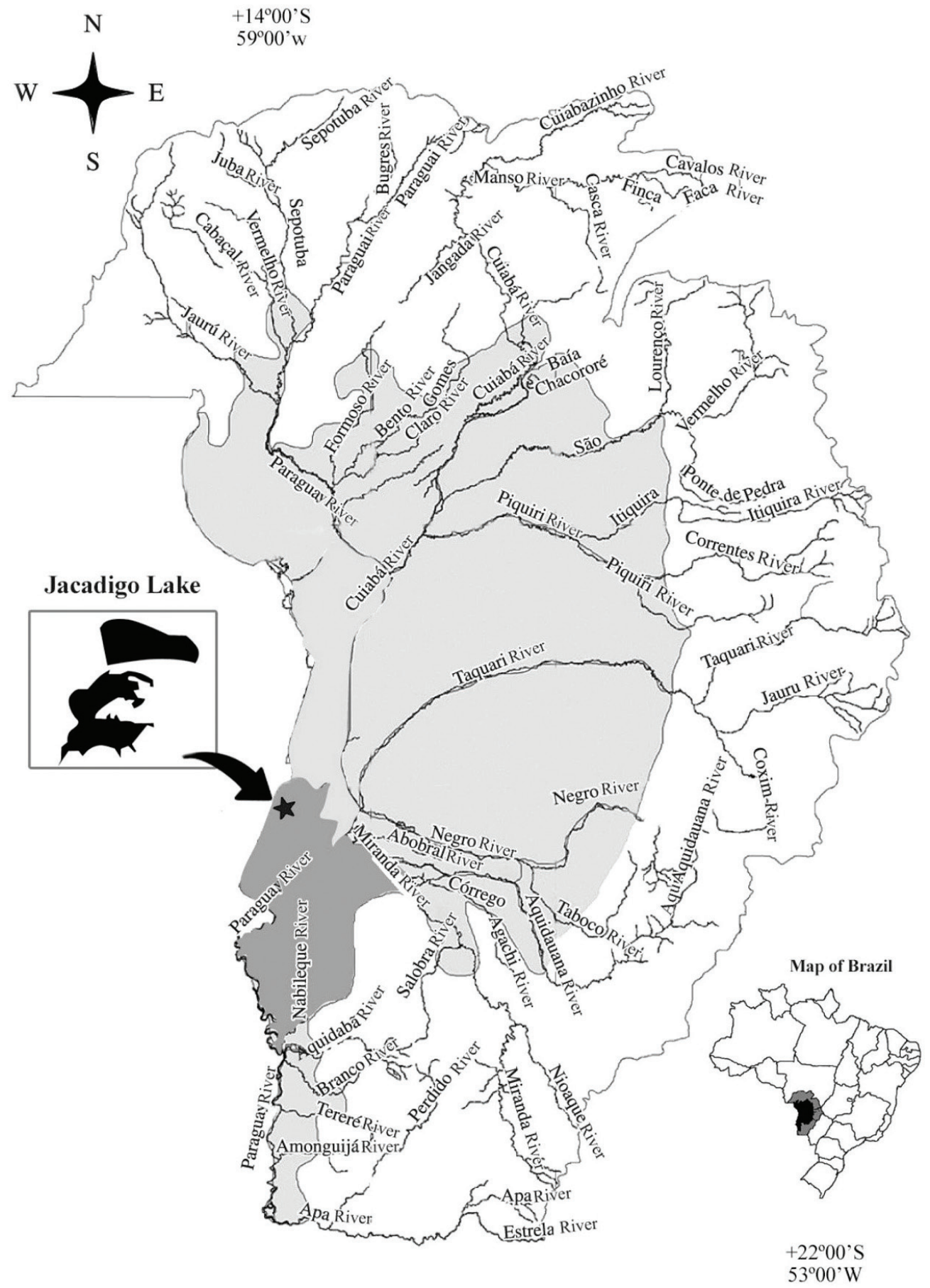

Figure 1. Study area: Pantanal, Mato Grosso do Sul, and map of Brazil with the Pantanal region highlighted in grey. Jacadigo lake, located in the sub-region of Nabileque (dark grey). Images: maps modified from Silva and Abdon (1998) and contour of the Jacadigo lake modified from Calheiros et al. (2006). 
$\mathbf{A}$

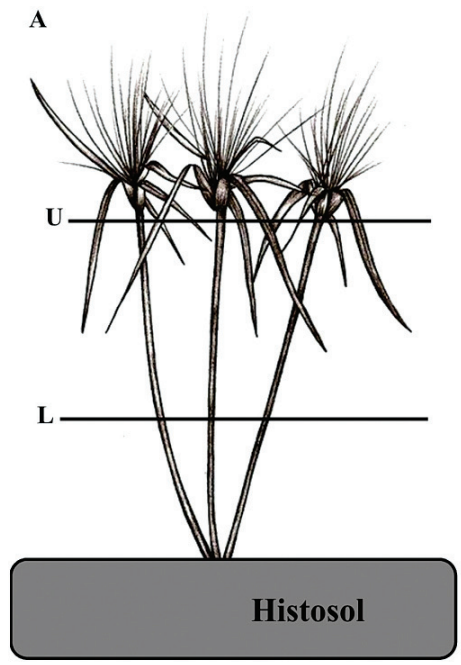

B

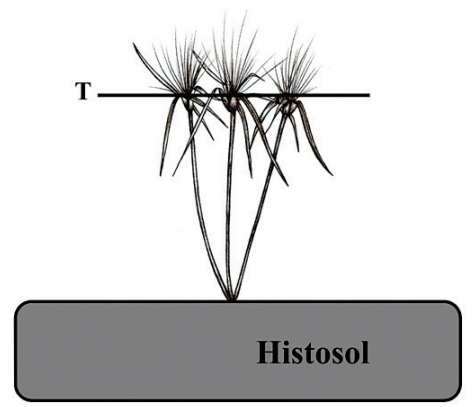

Figure 2. Sampling plots in vegetation to estimate visual coverage of plant species in monodominant formation of Cyperus giganteus in the Jacadigo lake, Corumbá, State of Mato Grosso do Sul: U) Upper stratum; L) Lower stratum and T) Total stratum.

the Universidade Federal do Mato Grosso do Sul, and consulting specialists. The collected fertile samples were incorporated into the Herbarium CGMS and families were listed according to APG III (2009).

\subsection{Analysis of data}

We built matrices with monthly data of percentage of cover per species, considering two evaluated strata (upper and lower) of the sedge. With these matrices we performed a Detrended Correspondence Analysis (DCA) using the program PCORD-5. The analyzed parameters were: percentage of cover and Relative Frequency (RF) per species. The variables Relative Cover (RC) and RF were calculated according to Brower and Zar (1977), using Excel-2003 to analyze separately each sampled stratum. The data of percentage of cover were utilized to build a matrix of the total per species per plot (sum of upper and lower strata) per month of sampling. Then, the matrix of presence and absence was used to build a rarefaction curve of species, using the program EstimateSWin7.52.

Differences among monthly relative cover were analyzed by a Friedman test with the Wilcoxon post hoc test, where we compared the cover of each evaluated month in both strata separately. All these non-parametric tests were performed with $5 \%$ of significance level using the software PAST.

To calculate diversity we utilized the index of diversity of Shannon (H') at the base "e" and equability of Pielou (J') (Magurran, 1989), with replacement of values of number of individuals by percentage of cover (Munhoz and Felfili, 2008).

\section{Results}

A total of 44 species distributed in 37 genera and 21 families were found in both sampled periods. Before fire we found 28 species, 26 genera and 16 families. Cyperaceae
(5 spp.) and Poaceae (3 spp.) showed the highest richness, six families were represented by two species and eight had single species. In the post-fire period we found 34 species, 30 genera and 19 families, Cyperaceae (6 spp.) standing out as richest family, followed by Fabaceae ( $4 \mathrm{spp}$.), which had only two species before fire; seven families showed two species, and ten families had a single species (Table 1). There was no large difference in species richness due to fire (Figure 3).

The ordination analysis (DCA) shows two distinct groups: one in the period before fire, and another thereafter. The considered strata showed to be different in both evaluated periods. Samples were more similar in the post-fire period (Figure 4). Before fire, the community was made up basically by species such as Ludwigia tomentosa, Odontocarya tamoides, and Cissampelos pareira in the upper stratum, and Rhynchospora scutellata, Pityrogramma calomelanos, Thelypteris interrupta, Vernonanthura brasiliana and Fuirena umbellata in the lower stratum.

After fire, we observed a large gap all over the area, period when $C$. giganteus was in the resprouting phase, what increased incidence of sunlight on the water, benefiting some species such as Echinodorus glaucus, Cephalanthus glabratus and Cyperus odoratus that occurred together with Ludwigia nervosa. Except the last one, all disappeared after reestablishment of the full size of $C$. giganteus and consequent shading. In this period, the community structure changed, including wetland species such as Scleria macrophylla, Leersia hexandra, Mikania micrantha and Urera aurantiaca in the lower stratum, while the upper stratum did not show many species besides C. giganteus (Figure 4).

The indexes of diversity ( $\left.\mathrm{H}^{\prime}\right)$ and equability (J') stayed lower in both strata in the post-fire period compared to before fire. In general, soon after the wildfire, the upper stratum 
Table 1. Plant species, with respective families and growth habits found in the periods before and after fire in a monodominant formation of Cyperus giganteus in Jacadigo lake, Nabileque sub-region, Pantanal, Corumbá, State of Mato Grosso do Sul, Brazil. Life forms listed according to Irgang et al. (1984).

\begin{tabular}{|c|c|c|c|}
\hline Family/ Species & Habit/ Life form & Before Fire & After Fire \\
\hline \multicolumn{4}{|l|}{ ALISMATACEAE } \\
\hline Echinodorus glaucus Rataj & Emergent herb & & $\mathrm{X}$ \\
\hline Echinodorus paniculatus Micheli & Emergent herb & $\mathrm{X}$ & \\
\hline \multicolumn{4}{|l|}{ APOCYNACEAE } \\
\hline Rhabdadenia madida (Vell.) Miers & Emergent vine & $\mathrm{X}$ & $\mathrm{X}$ \\
\hline \multicolumn{4}{|l|}{ ARACEAE } \\
\hline Pistia stratiotes $\mathrm{L}$. & Free floating herb & & $\mathrm{X}$ \\
\hline \multicolumn{4}{|l|}{ ASTERACEAE } \\
\hline Mikania micrantha Kunth & Emergent vine & $\mathrm{X}$ & $\mathrm{X}$ \\
\hline Vernonanthura brasiliana (L.) H.Rob. & Amphibious shrub & $\mathrm{X}$ & \\
\hline \multicolumn{4}{|l|}{ CONVOLVULACEAE } \\
\hline Ipomoea rubens Choisy & Emergent vine & $\mathrm{X}$ & \\
\hline Merremia umbellata (L.) Hallier f. & Amphibious vine & & $\mathrm{X}$ \\
\hline \multicolumn{4}{|l|}{ CUCURBITACEAE } \\
\hline Melothria cf. hirsuta Cogn. & Amphibious vine & $\mathrm{X}$ & \\
\hline \multicolumn{4}{|l|}{ CYPERACEAE } \\
\hline Cyperus giganteus Vahl & Emergent herb & $\mathrm{X}$ & $\mathrm{X}$ \\
\hline Cyperus odoratus $\mathrm{L}$. & Amphibious herb & & $\mathrm{X}$ \\
\hline Cyperus rigens C.Presl & Amphibious herb & $\mathrm{X}$ & \\
\hline Eleocharis elegans (Kunth) Roem. \& Schult. & Emergent herb & & $\mathrm{X}$ \\
\hline Eleocharis interstincta (Vahl) Roem. \& Schult. & Emergent herb & $\mathrm{X}$ & \\
\hline Fuirena umbellata Rottb. & Emergent herb & $\mathrm{X}$ & $\mathrm{X}$ \\
\hline Rhynchospora scutellata Griseb. & Emergent herb & $\mathrm{X}$ & $\mathrm{X}$ \\
\hline Scleria macrophylla J.Pres1 \& C.Pres1 & Emergent herb & & $\mathrm{X}$ \\
\hline \multicolumn{4}{|l|}{ FABACEAE } \\
\hline Aeschynomene fluminensis Vell. & Amphibious subshrub & & $\mathrm{X}$ \\
\hline Canavalia mattogrossensis (Barb.Rodr.) Malme & Emergent vine & $\mathrm{X}$ & $\mathrm{X}$ \\
\hline Vigna adenantha (G.Mey.) Maréchal et al. & Amphibious climbing herb & & $\mathrm{X}$ \\
\hline Vigna longifolia (Benth.) Verdc. & Emergent climbing herb & $\mathrm{X}$ & $\mathrm{X}$ \\
\hline \multicolumn{4}{|l|}{ MALVACEAE } \\
\hline Abutilon cf. ramiflorum A.St.-Hil. & Amphibious shrub & $\mathrm{X}$ & $\mathrm{X}$ \\
\hline Helicteres guazumifolia Kunth & Amphibious shrub & $\mathrm{X}$ & \\
\hline Hibiscus furcellatus Desr. & Emergent shrub & & $\mathrm{X}$ \\
\hline \multicolumn{4}{|l|}{ MELASTOMATACEAE } \\
\hline Rhynchanthera novemnervia DC. & Amphibious subshrub & $\mathrm{X}$ & \\
\hline \multicolumn{4}{|l|}{ MENISPERMACEAE } \\
\hline Cissampelos pareira $\mathrm{L}$. & Emergent vine & $\mathrm{X}$ & $\mathrm{X}$ \\
\hline Odontocarya tamoides (DC.) Miers & Emergent vine & $\mathrm{X}$ & $\mathrm{X}$ \\
\hline \multicolumn{4}{|l|}{ ONAGRACEAE } \\
\hline Ludwigia nervosa (Poir.) H.Hara & Emergent shrub & $\mathrm{X}$ & $\mathrm{X}$ \\
\hline Ludwigia tomentosa (Cambess.) H.Hara & Emergent shrub & $\mathrm{X}$ & $\mathrm{X}$ \\
\hline \multicolumn{4}{|l|}{ POACEAE } \\
\hline Leersia hexandra Sw. & Emergent herb & $\mathrm{X}$ & $\mathrm{X}$ \\
\hline Steinchisma laxum (Sw.) Zuloaga & Emergent herb & $\mathrm{X}$ & \\
\hline Stephostachys mertensii (Roth) Zuloaga \& Morrone & Emergent herb & $\mathrm{X}$ & $\mathrm{X}$ \\
\hline \multicolumn{4}{|c|}{ POLYGONACEAE } \\
\hline Polygonum hydropiperoides Michx. & Emergent herb & & $\mathrm{X}$ \\
\hline \multicolumn{4}{|l|}{ PONTEDERIACEAE } \\
\hline Pontederia parviflora Alexander & Emergent herb & & $\mathrm{X}$ \\
\hline Pontederia rotundifolia L.f. & Rooted floating herb & & $\mathrm{X}$ \\
\hline
\end{tabular}


Table 1. Continued...

\begin{tabular}{|c|c|c|c|}
\hline Family/ Species & Habit/ Life form & Before Fire & After Fire \\
\hline \multicolumn{4}{|l|}{ PTERIDACEAE (Pteridophyte) } \\
\hline Pityrogramma calomelanos (L.) Link & Emergent herb & $\mathrm{X}$ & $\mathrm{X}$ \\
\hline \multicolumn{4}{|l|}{ RUBIACEAE } \\
\hline Cephalanthus glabratus (Spreng.) K.Schum. & Amphibious shrub & $\mathrm{X}$ & $\mathrm{X}$ \\
\hline Diodella radula (Willd. ex Roem. \& Schult.) Delprete & Emergent herb & $\mathrm{X}$ & \\
\hline Spermacoce glabra Michx. & Herb & & $\mathrm{X}$ \\
\hline \multicolumn{4}{|l|}{ THELYPTERIDACEAE (Pteridophyte) } \\
\hline Thelypteris interrupta (Willd.) K.Iwats. & Emergent herb & $\mathrm{X}$ & $\mathrm{X}$ \\
\hline \multicolumn{4}{|l|}{ URTICACEAE } \\
\hline Cecropia pachystachya Trécul & Amphibious tree & & $\mathrm{X}$ \\
\hline Urera aurantiaca Wedd. & Amphibious subshrub & & $\mathrm{X}$ \\
\hline \multicolumn{4}{|l|}{ VERBENACEAE } \\
\hline Bouchea fluminensis (Vell.) Moldenke & Subshrub & & $\mathrm{X}$ \\
\hline \multicolumn{4}{|l|}{ VITACEAE } \\
\hline Cissus erosa Rich. & Emergent vine & $X$ & $\mathrm{X}$ \\
\hline
\end{tabular}

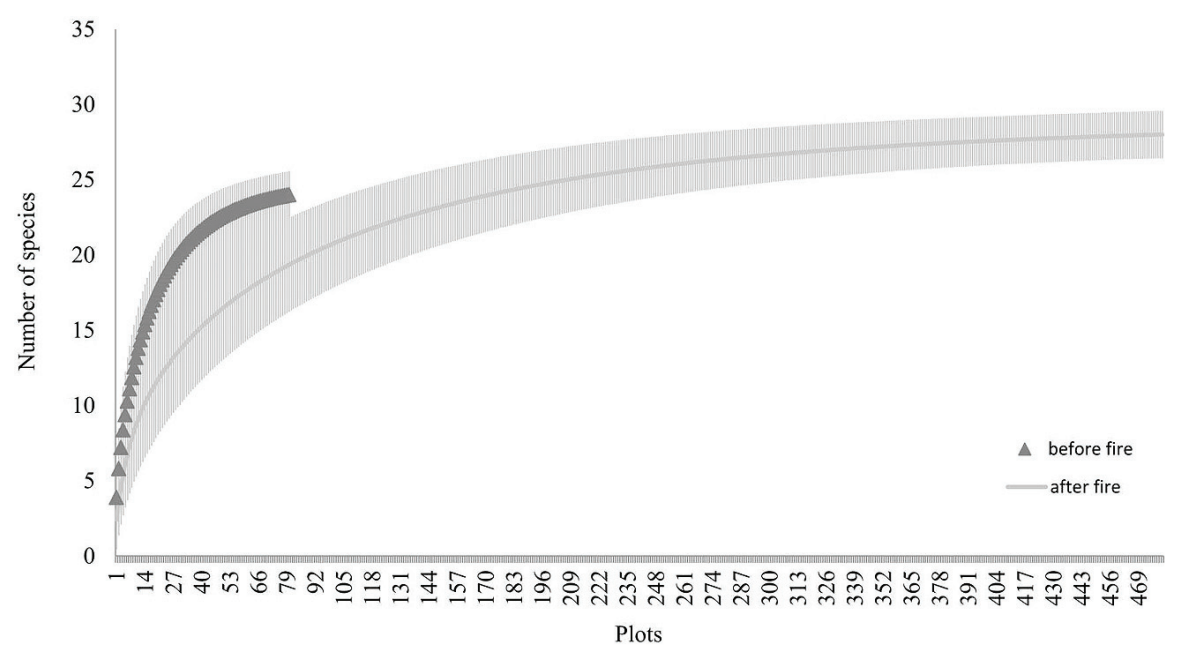

Figure 3. Rarefaction curves of number of species per sampling units (plots) in the Jacadigo lake before (July and August 2010) and after (October 2010 to September 2011) the fire.

presented smaller indexes compared to the lower stratum, except April and May, at the peak of flood (Figure 5).

Some rhizomatous species survived to fire, however had reduced RC and RF in the lower stratum, such as Rhynchospora scutellata, Pityrogramma calomelanos, Thelypteris interrupta and Fuirena umbellata. The shrub Ludwigia tomentosa appeared in both strata in both periods, though with reduced RC and RF after fire in both strata (Table 2).

The dominance of $C$. giganteus expressed by relative cover (RC) showed significant differences in both assessed strata among sampled months (Friedman test $\mathrm{p}<0.0001$ and Wilcoxon test $p<0.05$, Table 3 , Figure 6 ). The detected differences occurred between both months before fire and indistinctly in the months after fire, without clear relation with the fire event. The variation of RF followed similar tendency over time (Figure 6).

\section{Discussion}

Although burning changed the community structure of $C$. giganteus, one year after the fire event the number of species was reestablished. Such situation shows that the community, in terms of richness, is resistant (sensu Townsend et al., 2006) to disturbance, since in spite of the expected variation soon after burn, richness had recovered. Under an external disturbance, such as fire, some communities are able to modify their structure with constant change of species, leaving or entering the system, what characterizes the process of ecological succession (Pinto-Coelho, 2000). In this case, trend of maintenance of species richness is attributed to both resprouting and seedling recruitment.

The differences after fire revealed by DCA can be attributed mainly to features like changes in stratification; 


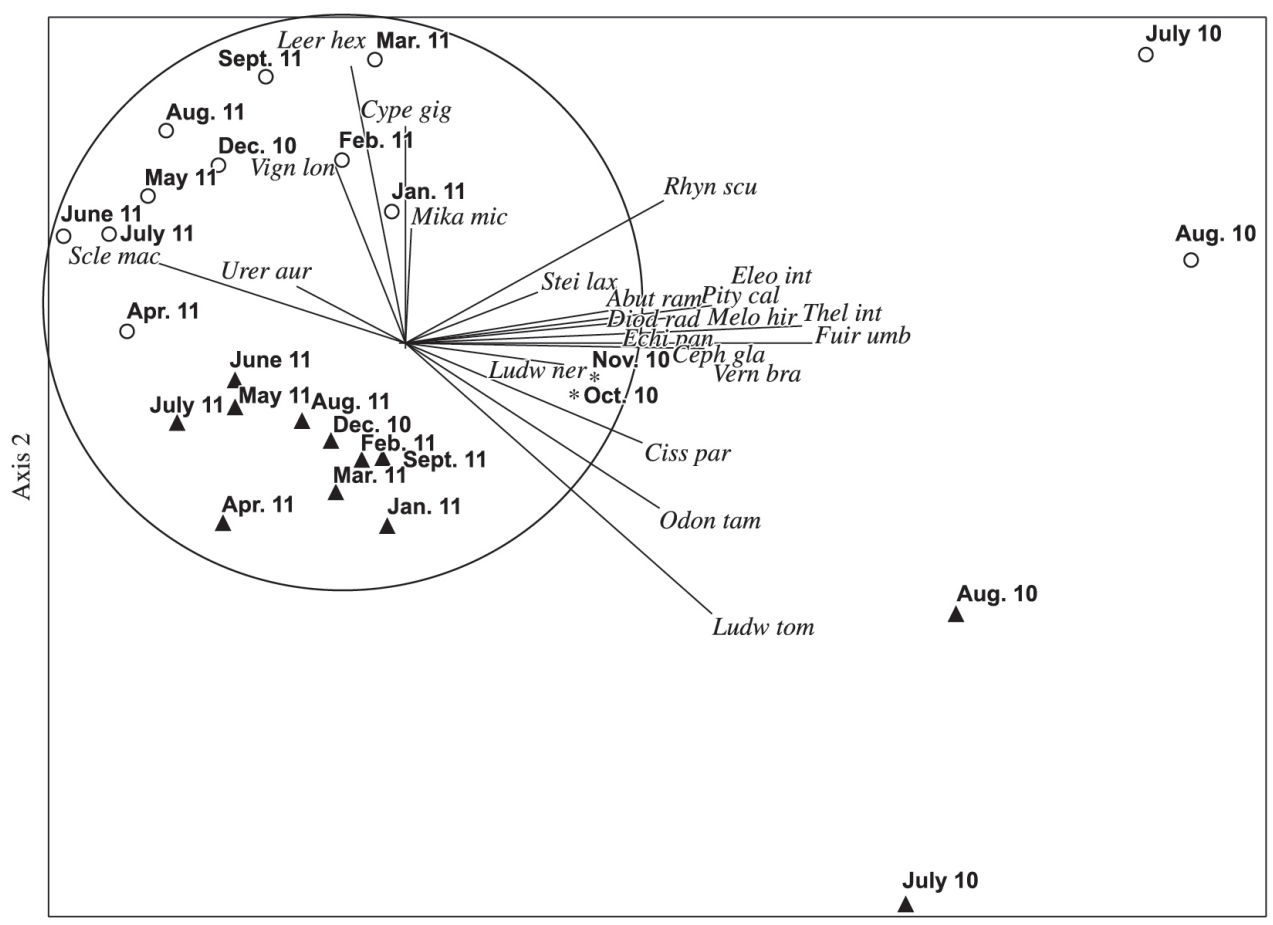

Axis 1

Figure 4. Detrended Correspondence Analysis (DCA) performed in the matrix of the percent of cover per species in different periods of the year in the upper $(\boldsymbol{\Delta})$ and lower strata $(\circ)$. Two months after fire only one stratum was considered, the total ${ }^{*}$ ). The months and scientific names are represented by the four initials letters and the years 2010 and 2011 by 10 and 11 , respectively. The circled area includes the samples performed after the fire event.
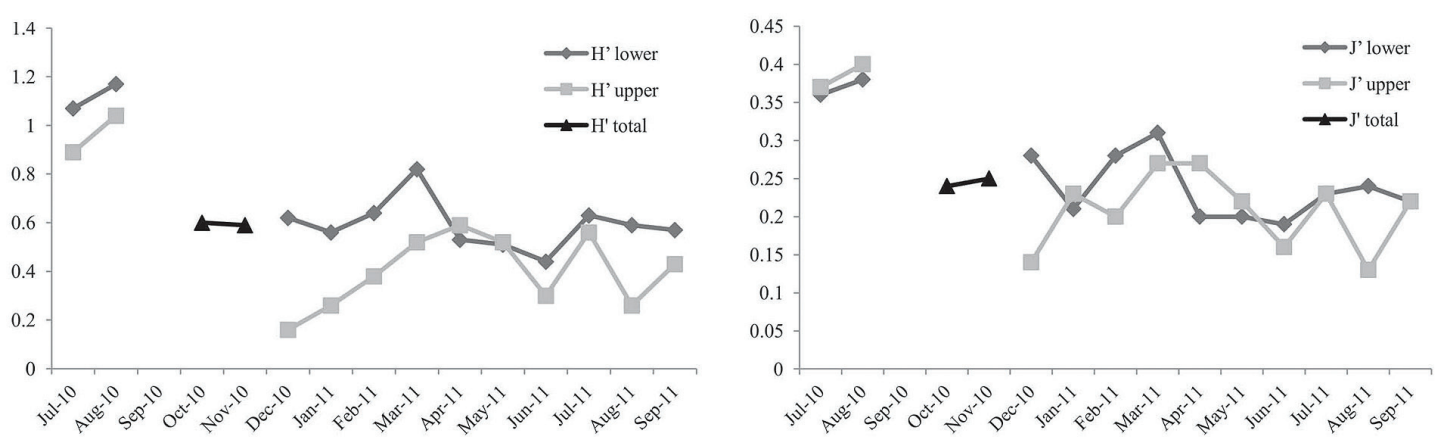

Figure 5. Variation of Shannon diversity index ( $\left.\mathrm{H}^{\prime}\right)$ and Pielou equability ( $\left.\mathrm{J}^{\prime}\right)$ in the community of Cyperus giganteus in Jacadigo lake, Pantanal, Mato Grosso do Sul, before and after fire.

emergency from the seed bank, plants which germinate seasonally and opportunistic species which germinate only after fire, and species which resprout after fire or indistinctly throughout the year. Before fire there was a well defined stratification, with vines such as Cissampelos pareira and Odontocarya tamoides, and the shrub Ludwigia tomentosa characterizing the upper stratum, and herbaceous species such as Rhynchospora scutellata, Pityrogramma calomelanos and Echinodorus paniculatus in the lower stratum. The first two months after fire (October and November 2010), when only the total stratum was evaluated, $C$. giganteus was in the resprouting phase, allowing light to reach the marshy ground. Species replacement in the community occurred when $C$. giganteus height stabilized, with adult plants reaching above $2 \mathrm{~m}$. Shading by $C$. giganteus quickly (within one year) selected species with tolerance to shade or to fire, or gap colonizers.

Some species cited in literature as fire sensitive and colonizers of burned areas, e.g Canavalia mattogrossensis and Odontocarya tamoides (Pott and Pott, 1994) were found in our study in both sampling periods. Nevertheless, species like Urera aurantiaca and Cecropia pachystachya found only after disturbance and mentioned as pioneers and common in gaps (Pott and Pott, 1994) clearly appear 
Table 2. Relative cover $(\mathrm{RC})$ and relative frequency $(\mathrm{RF})$ in the upper and lower strata of the species found in a monodominant formation of Cyperus giganteus before and after a fire event in Jacadigo lake, Corumbá, (State of Mato Grosso do Sul). The values of RC and RF of plants found outside the plots, open spaces (of the upper stratum), water (of the lower stratum), and organic matter are not presented.

\begin{tabular}{|c|c|c|c|c|c|c|c|c|}
\hline \multirow[b]{2}{*}{ PERÍOD } & \multicolumn{4}{|c|}{ BEFORE FIRE } & \multicolumn{4}{|c|}{ AFTER FIRE } \\
\hline & \multicolumn{4}{|c|}{ JULY AND AUGUST 2010} & \multicolumn{4}{|c|}{$\begin{array}{c}\text { DECEMBER } 2010 \text { TO SEPTEMBER } \\
2011\end{array}$} \\
\hline \multirow{2}{*}{ Species STRATUM } & \multicolumn{2}{|c|}{ UPPER } & \multicolumn{2}{|c|}{ LOWER } & \multicolumn{2}{|c|}{ UPPER } & \multicolumn{2}{|c|}{ LOWER } \\
\hline & RC & RF & RC & RF & RC & RF & RC & RF \\
\hline Abutilon cf. ramiflorum & . & . & 0.24 & 0.95 & . &. & 0.02 & 0.22 \\
\hline Aeschynomene fluminensis & . & . & . & . & . & . & 0.02 & 0.22 \\
\hline Canavalia mattogrossensis & . & . & 0.07 & 0.32 & 0.08 & 0.36 & 0.07 & 0.45 \\
\hline Cecropia pachystachya & . & . & . & . & . & . & 0.03 & 0.23 \\
\hline Cephalanthus glabratus & 0.29 & 1.04 & 0.28 & 1.87 & . & . & . & . \\
\hline Cissampelos pareira & 0.48 & 1.75 & 0.13 & 0.63 & . & . & 0.01 & 0.07 \\
\hline Cissus erosa & 0.14 & 1.04 & 0.1 & 0.64 & 0.04 & 0.35 & 0.19 & 1.57 \\
\hline Cyperus giganteus & 50.81 & 27.08 & 65.52 & 24.55 & 54.64 & 39.41 & 62.90 & 30.68 \\
\hline Diodella radula & . & . & 0.21 & 1.27 & . & . & . & . \\
\hline Echinodorus glaucus & . & . & . & . & . & . & 0.01 & 0.08 \\
\hline Echinodorus paniculatus & . & . & 0.12 & 0.32 & . & . & . & . \\
\hline Eleocharis elegans & . & . & . & . & 0.01 & 0.10 & 0.01 & 0.17 \\
\hline Eleocharis interstincta & 0.02 & 0.34 & 0.34 & 1.57 & . & . & . & . \\
\hline Fuirena umbellata & 1.42 & 7.98 & 4.24 & 11.01 & 0.08 & 0.39 & 0.09 & 0.38 \\
\hline Ipomoea rubens & 0.63 & 1.81 & 0.07 & 0.64 & . & . & . & . \\
\hline Leersia hexandra & . & . & 0.07 & 0.62 & 0.01 & 0.09 & 0.50 & 4.53 \\
\hline Ludwigia nervosa & 1.77 & 2.18 & 0.94 & 2.24 & 0.18 & 0.85 & 0.18 & 0.98 \\
\hline Ludwigia tomentosa & 11.64 & 17.50 & 5.33 & 13.82 & 3.12 & 7.82 & 1.55 & 5.80 \\
\hline Melothria cf. hirsuta & . & . & 0.04 & 0.63 & . & . & . & . \\
\hline Merremia umbellata & . & . & . & . & . & . & 0.02 & 0.15 \\
\hline Mikania micrantha & . & . & 0.13 & 1.28 & . & . & 0.10 & 0.23 \\
\hline Odontocarya tamoides & 1 & 3.11 & 0.37 & 2.83 & 0.01 & 0.09 & 0.02 & 0.22 \\
\hline Pistia stratiotes & . & . & . & . & . & . & 0.003 & 0.07 \\
\hline Pityrogramma calomelanos & 0.05 & 0.36 & 1.32 & 2.20 & . & . & 0.04 & 0.87 \\
\hline Polygonum hydropiperoides & . & . & . & . & 0.02 & 0.17 & 0.03 & 0.22 \\
\hline Rhabdadenia madida & 0.03 & 0.34 & 0.1 & 0.95 & 0.05 & 0.47 & 0.04 & 0.29 \\
\hline Rhynchospora scutellata & 1.08 & 4.6 & 10.66 & 10.34 & 0.26 & 1.71 & 2.05 & 4.41 \\
\hline Scleria macrophylla & . & . & . & . & 1.13 & 4.77 & 2.54 & 7.29 \\
\hline Spermacoce glabra & . & . & . & . & . & . & 0.02 & 0.08 \\
\hline Steinchisma laxum & . & . & 0.17 & 0.93 & . & . & . & . \\
\hline Stephostachys mertensii & . & . & . & . & 0.02 & 0.10 & 0.03 & 0.21 \\
\hline Thelypteris interrupta & 0.28 & 1.75 & 1.22 & 3.15 & . & . & 0.02 & 0.07 \\
\hline Urera aurantiaca & . & . & . & . & 0,02 & 0,26 & 0,22 & 1,51 \\
\hline Vernonanthura brasiliana & 0.25 & 0.36 & 0.28 & 0.63 & . & . & . & . \\
\hline Vigna adenantha & . & . & . & . & 0.10 & 0.64 & 0.05 & 0.37 \\
\hline Vigna longifolia & 0.2 & 1.45 & 0.12 & 1.88 & 0.25 & 3.10 & 0.84 & 7.83 \\
\hline
\end{tabular}

here due to the light reaching the histosol after fire. Species with annual behavior such as Pistia stratiotes, Cyperus odoratus and Pontederia rotundifolia also appeared only after fire. This indicates that the histosol keeps a seed bank with rather opportunistic species which may determine the post-fire community structure. The seed bank can indicate which species becomes established after a disturbance or when conditions are adequate for germination (Cronk and Fennessy, 2001).

Among the species found before fire, Echinodorus paniculatus, Rhabdadenia madida, Ipomoea rubens, Leersia hexandra, Ludwigia nervosa, L. tomentosa, Pityrogramma calomelanos and Rhynchanthera novemnervia are plants common on histosols of floating meadows in more advanced 
Table 3. Diagonal matrix showing the p-values for the Wilcoxon post hoc test (after Friedman test $p<0.05$ ) on the assessed values for comparison of relative cover (RC) of Cyperus giganteus in the sampled months. Periods before (July and August 2010) and after fire (December 2010 to September 2011). Significant $(\mathrm{p}<0.05)$ outcomes of the test are highlighted.

\begin{tabular}{|c|c|c|c|c|c|c|c|c|c|c|c|c|}
\hline & $\begin{array}{c}\text { July- } \\
10\end{array}$ & $\begin{array}{c}\text { Aug- } \\
10\end{array}$ & $\begin{array}{c}\text { Dec- } \\
10\end{array}$ & Jan-11 & Feb-11 & $\begin{array}{c}\text { Mar- } \\
11\end{array}$ & $\begin{array}{c}\text { Apr- } \\
11\end{array}$ & $\begin{array}{c}\text { May- } \\
11\end{array}$ & $\begin{array}{c}\text { June- } \\
11 \\
\end{array}$ & $\begin{array}{c}\text { July- } \\
11\end{array}$ & $\begin{array}{c}\text { Aug- } \\
11\end{array}$ & $\begin{array}{c}\text { Sept- } \\
11\end{array}$ \\
\hline Jul-10 & & 0.03 & 0.19 & 0.03 & 0.02 & 0.09 & 0.17 & 0.16 & 0.02 & 0.21 & 0.01 & 0.90 \\
\hline Aug-10 & - & & 0.62 & 0.89 & 0.35 & 0.59 & 0.26 & 0.38 & 0.74 & 0.06 & 0.14 & 0 \\
\hline Dec-10 & - & - & & 0.39 & 0.07 & 0.87 & 0.44 & 0.93 & 0.25 & 0.26 & 0.03 & 0 \\
\hline Jan-11 & - & - & - & & 0.51 & 0.4 & 0.08 & 0.40 & 0.84 & 0.04 & 0.14 & 0 \\
\hline Feb-11 & - & - & - & - & & 0.06 & 0 & 0.08 & 0.24 & 0.01 & 0.49 & 0 \\
\hline Mar-11 & - & - & - & - & - & & 0.12 & 0.73 & 0.26 & 0.08 & 0.01 & 0 \\
\hline Apr-11 & - & - & - & - & - & - & & 0.56 & 0.04 & 0.56 & 0 & 0.02 \\
\hline May-11 & - & - & - & - & - & - & - & & 0.34 & 0.24 & 0.03 & 0 \\
\hline Jun-11 & - & - & - & - & - & - & - & - & & 0.04 & 0.31 & 0 \\
\hline Jul-11 & - & - & - & - & - & - & - & - & - & & 0 & 0.09 \\
\hline Aug-11 & - & - & - & - & - & - & - & - & - & - & & 0 \\
\hline Sep-11 & - & - & - & - & - & - & - & - & - & - & - & \\
\hline \multicolumn{13}{|c|}{ LOWER STRATUM } \\
\hline & $\begin{array}{c}\text { July- } \\
10\end{array}$ & $\begin{array}{c}\text { Aug- } \\
10\end{array}$ & $\begin{array}{c}\text { Dec- } \\
10\end{array}$ & Jan-11 & Feb-11 & $\begin{array}{c}\text { Mar- } \\
11\end{array}$ & $\begin{array}{c}\text { Apr- } \\
11\end{array}$ & $\begin{array}{c}\text { May- } \\
11\end{array}$ & $\begin{array}{c}\text { June- } \\
11\end{array}$ & $\begin{array}{c}\text { July- } \\
11\end{array}$ & $\begin{array}{c}\text { Aug- } \\
11\end{array}$ & $\begin{array}{c}\text { Sept- } \\
11\end{array}$ \\
\hline Jul-10 & & 0.35 & 0.14 & 0.15 & 0.04 & 0.16 & 0.78 & 0.98 & 0.84 & 0.98 & 0.37 & 0.63 \\
\hline Aug-10 & - & & 0.03 & 0.01 & 0 & 0.03 & 0.44 & 0.46 & 0.79 & 0.48 & 0.78 & 0.72 \\
\hline Dec-10 & - & - & & 0.38 & 0.43 & 0.96 & 0.09 & 0.01 & 0.01 & 0.05 & 0 & 0.01 \\
\hline Jan-11 & - & - & - & & 0.57 & 0.32 & 0.01 & 0 & 0 & 0 & 0 & 0 \\
\hline Feb-11 & - & - & - & - & & 0.40 & 0.03 & 0 & 0 & 0.01 & 0 & 0 \\
\hline Mar-11 & - & - & - & - & - & & 0.10 & 0.02 & 0.02 & 0.04 & 0 & 0.01 \\
\hline Apr-11 & - & - & - & - & - & - & & 0.20 & 0.36 & 0.83 & 0.02 & 0.32 \\
\hline May-11 & - & - & - & - & - & - & - & & 0.96 & 0.21 & 0.29 & 0.87 \\
\hline Jun-11 & - & - & - & - & - & - & - & - & & 0.28 & 0.22 & 0.97 \\
\hline Jul-11 & - & - & - & - & - & - & - & - & - & & 0.03 & 0.42 \\
\hline Aug-11 & - & - & - & - & - & - & - & - & - & - & & 0.15 \\
\hline Sep-11 & - & - & - & - & - & - & - & - & - & - & - & \\
\hline
\end{tabular}
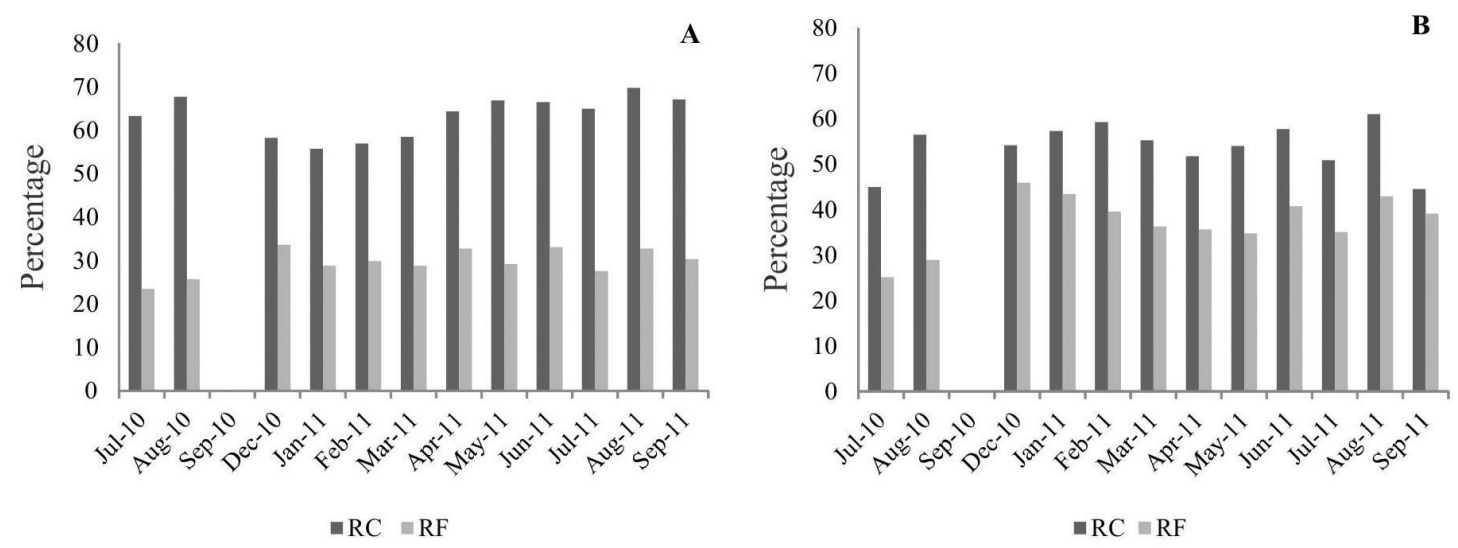

Figure 6. Variation of Relative Cover (RC) and Relative Frequency (RF) in two strata of Cyperus giganteus before and after the fire event in September 2010 in the Jacadigo lake, Pantanal of Nabileque. The months of October and November 2010 do not appear in the graphic, because then only one stratum occurred. A) Lower stratum and B) Upper stratum. 
stages of succession (Pivari et al., 2008; Cunha et al., 2012). Most of them persisted after fire, with a relatively fast restart of succession, some of them from buried regenerative structures and others from soil seed bank.

Soon after fire, the floristic composition of both strata became more similar because the species which have the capacity to reach the upper stratum of the community (vines and shrubs) were in process of growth, after colonizing the lower stratum. So, in the post-fire period, vines and shrubs also characterize the lower stratum, while the upper one does not yet have characteristic species.

Both diversity (H') and equability (J') were lower after fire, since only fast colonization species such as Scleria macrophylla, Leersia hexandra and Urera aurantiaca showed high RC compared to other species of slower colonization. Reduction of diversity during succession in wet grasslands is due to fast growing competitive rhizomatous species (Rosenthal, 2010).

In contrast, before fire, the community presented species of fast colonization, as well as slow ones such as Vernonanthura brasiliana and Rhynchanthera novemnervia, with higher $\mathrm{RC}$ values. This way the indexes of diversity $\left(H^{\prime}\right)$ and equability (J') were higher in the pre-burn period, what seems to be a trend in herbaceous communities. Species diversity is also higher in rarely burned grass communities affected by both fire and bison grazing in Kansas (Collins and Calabrese, 2012). Fire in grasslands, in the first years after the event, stimulates growth and provokes competitive exclusion, reducing diversity (Huston, 1994).

The fast resprouting of $C$. giganteus in the whole community after top-kill occurred due to the vigorous rhizome. This strategy is common in herbaceous species which occur in fire-prone zones where rhizomatous grasses resprout after wildfires (Choczynska and Johnson, 2009).

The RF of species increased in the post-fire period, mainly in the upper stratum, due to the fast growth of C. giganteus compared to other species, such as shrubs and vines which have the capacity to reach the upper stratum. In general the RF of these companion species was low shortly after fire.

Although there were differences in relative cover of C. giganteus in the evaluated 12 months, these differences cannot be attributed to the fire event, since there were months with higher and lower RC after fire. In a broad way, our results are similar to long term effects of fire on monodominant community of Cladium jamaicense (Cyperaceae) associated with Typha domingensis, both rhizomatous aquatic plants with unaltered density (Ponzio et al., 2004). Our findings also agree with studies by Salvia et al. (2012) on the effects of fire on the Cyperus giganteus and Schoenoplectus californicus (Cyperaceae) community in the Paraná river delta, Argentina, where usually after a growth period (ca. six months) it again reached a cover similar to unburned areas. Regarding dominance of $C$. giganteus, we verified that fire practically does not affect the sedge cover. This partially confirms our initial hypothesis, since the species quickly replaced its previous cover only two months after fire. So, the monodominance of $C$. giganteus, in spite of be an aquatic species, is not affected by fire events.

\section{Conclusion}

Fire can change the structure of the Cyperus giganteus community because some species appear only after fire and others later on, but richness is recovered within months because some sensitive species are replaced by fast growing, light demanding opportunistic species, and others can resprout or germinate from the seed bank.

Cyperus giganteus can vigorously resprout soon after fire and this event can not affect the cover and consequently the dominance of this species. This confirms partially our initial hypothesis once this species is not clearly favored by fire but its ecological status is maintained after this event.

\section{Acknowledgements}

To the Brazilian official agencies CNPq and CAPES for scholarship to M. Rocha, C.C. Santos Júnior and research grants to A. Pott, to CPP/INAU (Brazilian Institute for Wetland Research) for financial support, to Francielli Bao for botanical illustration, to Rosa Helena da Silva and many undergraduate students for help at fieldwork, and to Dr. Catia Nunes da Cunha and Dr. Fernando Ferreira for the previous review of the manuscript.

\section{References}

ADÁMOLI, J., 2000. O limite sul do Pantanal. In Anais do III Simpósio sobre Recursos Naturais e Sócio-econômicos do Pantanal: Os Desafios do Novo Milênio, 2000, Corumbá. p. 1-15.

ALLEM, AC. and VALLS, JFM., 1987. Recursos forrageiros nativos do Pantanal Mato-Grossense. Brasília: Embrapa/Departamento de Difusão de Tecnologia. 339 p.

Angiosperm Phylogeny Group APG III, 2009. An update of the Angiosperm Phylogeny Group classification for the orders and families of flowering plants: APG III. Botanical Journal of the Linnean Society, vol. 161, no. 2, p. 105-121. http://dx.doi. org/10.1111/j.1095-8339.2009.00996.x.

BEZERRA, MAO. and MOZETO, AA., 2008. Deposição de carbono orgânico na planície de inundação do rio Paraguai durante o Holoceno médio. Oecologia Brasiliensis, vol. 12, no. 1, p. 155171. http://dx.doi.org/10.4257/oeco.2008.1201.14.

BROWER, JE. and ZAR, JH., 1977. Field \& laboratory methods for general ecology. 2nd ed. Dubuque: Wm. C. Brown Publishers. $226 \mathrm{p}$.

CALHEIROS, DF., SALIS, SM., MOURÃO, GM., CAMPOLIM, AI., TOMÁS, WM., SORIANO, BMA. and GALVANI, F., 2006. Parecer técnico referente ao RIMA do empreendimento denominado EBX Siderurgia Ltda., elaborado pela CAL Consultoria Ambiental Ltda. Corumbá: Embrapa. Available from: $<$ http://www.riosvivos. org.br/bkp/arquivos/628736443.pdf>.

CHOCZYNSKA, J. and JOHNSON, EA., 2009. A soil heat and water transfer model to predict belowground grass rhizome bud death in a grass fire. Journal of Vegetation Science, vol. 20, no. 2, p. 277-287. http://dx.doi.org/10.1111/j.1654-1103.2009.05757.x. 
COLLINS, SL. and CALABRESE, LB., 2012. Effects of fire, grazing and topographic variation on vegetation structure in tallgrass prairie. Journal of Vegetation Science, vol. 23, no. 3, p. 563-575. http://dx.doi.org/10.1111/j.1654-1103.2011.01369.x.

COUTO, EG. and CHIG, LA., CUNHA, CN. and LOUREIRO, MF., 2006. Estudo sobre o impacto do fogo na disponibilidade de nutrientes, no banco de sementes e na biota de solos da RPPN SESC Pantanal. Rio de Janeiro: SESC/Departamento Nacional. 54 p. Conhecendo o Pantanal, no. 2.

CRISPIM, SMA. and SANTOS, SA., SORIANO, BMA. and DOMINGOS BRANCO, O., 2009. Fitofisionomias vegetais e incêndios no Pantanal. Corumbá: Embrapa Pantanal. 5 p. Comunicado Técnico, no. 81. Available from: $<$ http://www.cpap. embrapa.br/publicacoes/online/COT81.pdf $>$.

CRONK, JK. and FENNESSY, MS., 2001. Wetland plants: biology and ecology. Boca Raton: Lewis Publishers. 462 p.. http://dx.doi. org/10.1201/9781420032925.

CUNHA, NL., DELATORRE, M., RODRIGUES, RB., VIDOTTO, C., GONÇALVES, F., SCREMIN-DIAS, E., DAMASCENOJÚNIOR, G., POTT, VJ. and POTT, A., 2012. Structure of aquatic vegetation of a large lake, western border of the Brazilian Pantanal. Revista Brasileira de Biologia $=$ Brazilian Journal of Biology, vol. 72, no. 3, p. 519-531. http://dx.doi.org/10.1590/ S1519-69842012000300015. PMid:22990823

FIDELIS, A., MÜLLER, SC., PILLAR, VD. and PFADENHAUER, J., 2007. Efeito do fogo na ecologia de populações de herbáceas e arbustos dos campos sulinos. Revista Brasileira de Biociências, vol. 5, no. 1, p. 303-305.

FRANKLIN, DC., PRIOR, LD., HOGARTH, NJ. and MCMAHON, CR., 2010. Bamboo, fire and flood: consequences of disturbance for the vegetative growth of a clumping, clonal plant. Plant Ecology, vol. 208, no. 2, p. 319-332. http://dx.doi.org/10.1007/ s11258-009-9709-x.

HEINL, M., FROST, P., VANDERPOST, C. and SLIVA, J., 2007. Fire activity on drylands and floodplains in the southern Okavango, Delta, Botswana. Journal of Arid Environments, vol. 68, no. 1, p. 77-87. http://dx.doi.org/10.1016/j.jaridenv.2005.10.023.

HUSTON, MA., 1994. Biological diversity: the coexistence of species on changing landscapes. Cambridge: University Press. 681 p.

IRGANG, BE., PEDRALLI, G. and WAECHTER, JI., 1984. Macrófitos aquáticos da Estação Ecológica do Taim, Rio Grande do Sul, Brasil. Roessleria, vol. 6, p. 395-404.

KÖPPEN, W., 1948. Climatologia: con un estudio de los climas de la tierra. México: Fondo de Cultura Económica. 478 p.

LORENZI, H., 2008. Plantas daninhas do Brasil: terrestres, aquáticas, parasitas e tóxicas. 4. ed. Nova Odessa: Instituto Plantarum. $640 \mathrm{p}$.

MACEDO, HA., SILVA, A., NEVES, SMAS. and NEVES, RJ., 2009. Avaliação das queimadas no Pantanal do Paraguai na região de Corumbá e Ladário, MS no período de maio de 2009. In Anais $2^{\circ}$ Simpósio de Geotecnologias no Pantanal, 2009. Corumbá: Embrapa Informática Agropecuária/INPE. p. 452-459.

MAGURRAN, AE., 1989. Diversidad ecológica y su medición. España: Ediciones Vedrà. 199 p.

MITSCH, WJ. and GOSSELINK, JG., 2000. Wetlands. 3rd edition. New York: John Wiley \& Sons. 920 p.
MUNHOZ, CBR. and FELFILI, JM., 2008. Fitossociologia do estrato herbáceo-subarbustivo em campo limpo úmido no Brasil Central. Acta Botanica Brasilica, vol. 22, no. 4, p. 905-913. http:// dx.doi.org/10.1590/S0102-33062008000400002.

NEVES, ACO., BEDÊ, LC. and MARTINS, RP., 2011. Revisão sobre os efeitos do Fogo em Eriocaulaceae como subsídio para a sua conservação. Instituto Chico Mendes de Conservação da Biodiversidade, no. 2, p. 50-66. Available from: <www.icmbio. gov.br/revistaeletronica/index.php/BioBR/article/.../100>. Access in: 25 Nov. 2012.

PEREIRA, LE. and LAPERE, ACL., 2009. Análise multitemporal da lagoa do Jacadigo no município de Corumbá, MS. In Anais do $2^{\circ}$ Simpósio de Geotecnologias no Pantanal, 2009. Corumbá: Embrapa Informática Agropecuária/INPE. p. 240-248. Available from: <http://www.geopantanal2009.cnptia.embrapa.br/cd/pdf/ p167.pdf>.

PINTO-COELHO, RM., 2000. Fundamentos em ecologia. Porto Alegre: Artes Médicas Sul. 252 p.

PIVARI, MO., POTT, VJ. and POTT, A., 2008. Macrófitas aquáticas de ilhas flutuantes (baceiros) nas sub-regiões do Abobral e Miranda, Pantanal, MS, Brasil. Acta Botanica Brasilica, vol. 22, no. 2, p. 563-571. http://dx.doi.org/10.1590/S0102-33062008000200023.

PONZIO, KJ., MILLER, SJ. and LEE, MA., 2004. Long-term effects of prescribed fire on Cladium jamaicense crantz and Typha domingensis pers. densities. Wetlands Ecology and Management, vol. 12, no. 2, p. 123-133. http://dx.doi.org/10.1023/ B:WETL.0000021671.65897.0c

POTT, A., 2007. Dinâmica da vegetação do Pantanal. In Anais do VIII Congresso de Ecologia do Brasil, 2007, Caxambu, MG. p. 1-4.

POTT, A. and POTT, VJ., 1994. Plantas do Pantanal. Brasília: Embrapa. 320 p.

POTT, VJ. and POTT, A., 2000. Plantas aquáticas do Pantanal. Brasília: Embrapa. 404 p.

POTT, VJ. and POTT, A., 2003. Dinâmica da vegetação aquática do Pantanal. In THOMAZ, SM. and BINI, LM. (Eds.). Ecologia e manejo de macrófitas aquáticas. Maringá: Editora da Universidade Estadual de Maringá. p. 145-162.

ROSENTHAL, G., 2010. Secondary succession in a fallow central European wet grassland. Flora, vol. 205, no. 3, p. 153-160. http:// dx.doi.org/10.1016/j.flora.2009.02.003.

SALVIA, M., CEBALLOS, D., GRINGS, F., KARSZENBAUM, H. and KANDUS, P., 2012. Post-fire effects in wetland environments: landscape assessment of plant coverage and soil recovery in the Paraná River Delta Marshes, Argentina. Fire Ecology, vol. 8, no. 2, p. 17-37. http://dx.doi.org/10.4996/fireecology.0802017.

SCHESSL, M., 1999. Floristic composition and structure of floodplain vegetation in the northern Pantanal of Mato Grosso, Brazil. Phyton, vol. 39, no. 2, p. 303-336.

SILVA, JSV. and ABDON, MM., 1998. Delimitação do Pantanal brasileiro e suas sub-regiões. Pesquisa Agropecuaria Brasileira, vol. 33, p. 1703-1711

SORIANO, BMA., 1997. Caracterização climática de Corumbá, MS. Corumbá: Embrapa. 25 p. Boletim de Pesquisa, no. 11.

TOWNSEND, CR., BEGON, M. and HARPER, JL., 2006. Fundamentos em ecologia. Porto Alegre: Artes Médicas Sul. 592 p. 